\title{
Astronomy and ceremony at Chankillo: an Andean perspective
}

\author{
J. McKim Malville \\ Department of Astrophysical and Planetary Sciences, \\ University of Colorado, Boulder, Colorado 80309, USA \\ email: kim.malville@colorado.edu
}

\begin{abstract}
The towers, plazas, and fortified temple of Chankillo are analyzed within the context of Central Andean culture. Throughout the cultural area, staircases were apparently the scenes of ritual procession, perhaps mimicking shamanic-like movement between the three worlds. The double stairways of the thirteen towers of Chankillo may have been designed for ritual movement. The gradual rotation of the successively higher towers suggests shamanic ascent between the terrestrial and solar realms. The major astronomical feature of Chankillo is its solar axis, oriented to December solstice sunrise and June solstice sunset. Along this axis, to the east and west of the towers, there are prominent plazas in which public ceremonies may have been staged, particularly at the time of June solstice sunset. Celebrants who reached the highest tower on sunset of June solstice would have been silhouetted by the setting sun as viewed by spectators in the eastern plaza just below the tower. In the large plaza west of the towers, a similar public ceremony could have been associated with setting of the June solstice sun over the Temple of the Pillars to the west of the towers. The thirteen towers may have been stations of the moon for public ceremonies during the bright half of the lunar cycle. The presence of Spondylus shells suggests lunar ritual. The duality of private/public ritual, evident at Chavín and elsewhere, may have been present at Chankillo where public ceremonies may been observed from the plazas, while more restricted ceremonies may have occurred behind the walls of the fortified temple. If a horizon calendar had been developed using the profiles of the thirteen towers, it appears to have been an unintended consequence of the initial design of the towers. The monumental size of the towers is incommensurate with the small putative observing stations. The June solstice sun misses the lowest tower by 7 solar diameters, which would have been an unacceptable error if the tower had been built originally to mark June solstice. Another unsatisfactory feature would have been the equal spacing of the towers. If a meaningful calendar had been desired that marked divisions of the year perhaps based upon the moon, it would have involve variable spacing of the towers, with the largest spacing around equinox.
\end{abstract}

Keywords. Andean cultures, ritual processions, ceremonial stairways, towers, solar axes

\section{The Central Andean culture area}

Chankillo is embedded in the Central Andean culture area, an ethnographic concept suggested by Julio Tello (1923), who had proposed that Andean complex culture had originated in the highland at Chavín de Huántar and spread to the coast. Encouraged by Alfred Kroeber, Wendell Bennet (1948) proposed a Central Andean culture area that extended from Cajamarca on the north to Lake Titicaca on the south. There have been discussions of the northern and southern boundaries, but the core that includes Caral, Chavín de Huántar, the Casma Valley, and Moche, remains unchallenged. Among the characteristics of Central Andean culture that Bennet identified were intensive agriculture, irrigation, terracing, weaving, monumental public buildings, and long-distance pilgrimages. Trade was important in disseminating goods and ideas, but pilgrimage had the additional effect of honoring ancestors and their artifacts. Additional features of Central 
Andean culture are plazas for public ceremonies, huacas, ushnus, ancestor veneration, mountain worship, solar axes, and shamanic movement.

The importance of interrelationships and cultural continuities within the larger cultural area means that no unit, such as Chankillo, can be considered independent and isolated. This paper examines a number of features of Chankillo, such as its extensive stairways, plazas, solar axis, and hill top structure, sometimes known as the Fortress, in the broader context of Central Andean culture. The occupation of Chankillo, 320-200 BC, followed the decline of the power of Chavín de Huántar by perhaps two centuries. After the loss of its political and religious power, Chavín was reoccupied during the Chakinani phase (460-390 BC) and Janabarriu phase (390-200 BC) (Kembel 2008). During these later periods an extensive trade network developed. With its famous Lanzón, Chavín appears to have been a continuing destination of pilgrims through Inca times (Cummins 2008). Communities in the Casma Valley lying along the trade and pilgrimage route between the coast and Chavín should bear some imprint of its influences.

Before Chavín, interconnections along the coast extend back to the first entry of humans into South America (Dixon 1999). The oldest is Monte Verde in Chile around 14,220 RCYBP; coastal sites in Peru such as Quebrada Jaguay and Talara have dates of 11,105 RCYPB and 11,200 RCYBP (Gruhn 2006). Mosley (1975) and others have argued for the maritime foundations of Andean cultures because of the abundance of sea life and the presence of extensive shell fish middens. For these cultures, the moon was more important than the sun in establishing access to tidal area. Lives depended on attention to the phases of the moon, and it is not surprising that lunar ceremonialism, partly identified by Spondylus shell, developed along the coastal areas.

Early connections between the coast, the highlands, and the tropical forest are demonstrated by Guitarrero Cave north of Huaras in Callejón de Huaylas, between the Cordillera Blanca and the Cordillera Negra. The lowest level has yielded a date of 12,560 RCYBP (Gruhn 2006; Lynch 1985). What makes Guitarrero Cave so very interesting is that it is approached up the Casma Valley, over a pass in the Cordillera Negra. Its collection of textiles, basketry and evidence of early domesticated beans and chili pepper (10,600-8000 RCYBP) indicate trade to the east with the jungle. The fiberwork found in the cave, the earliest found in South America, includes fragments of twined basketry and bags, which may have been used for portage along early trade routes between the coast at the Casma Valley and the jungle.

\section{Movement}

Movement up the Casma valley to Chavín through the mountains of the Cordillera Negra and Blanca involves ascent and descent, which are constant themes in Andean cosmology and the ritualized world of pyramids. Tello recounted the story of a contemporary shaman which encapsulates many of the motifs of Andean cosmology: ascent to the mountain or ascent of the pyramid, offerings of water, and shamanic transformation (cf. Eliade 1964).

"Wari is the God of force; according to a legend common to almost the whole Andean region it was he who constructed the irrigation dams and channels that remain from the prosperous agricultural past. When in former times the local shaman went to visit him in his mountain range, at the lake formed at the mountain's foot by the melting ice, they would always take human blood mixed with maize flour as an offering; and his successors today still take offerings of animal blood and flour, and throw them into the lake.... When it does not rain in the mountainous areas and a bad year for agriculture is threatened, the shaman will descend to the coast ... and gather a small amount of water from the ... 
sea: this water will be carefully guarded in a canteen flask; through certain ceremonies the shaman identifies himself with the spirit of the water he is carrying up into the mountains. As he ascends, he will from time to time let loose roars that imitate a feline beast ... The shaman leaves some of the water in the wells that he passes and on finally arriving at the lake, tips out the rest, little by little. A cloud is then said to come out of the canteen flask and darken the air, setting loose the storm which will inaugurate the rainy season." (Tello 1923)

Pyramids are symbolic mountains. Stairways are the routes of ritual ascent. Caral has six pyramids (Shady 2006), the largest being the Great Pyramid with a height of $20 \mathrm{~m}$ and a 9m-wide staircase that leads upward from a circular plaza. Other coastal sites, such as Cerro Sechín, Sechín Bajo, Las Haldas, and Moche abound with pyramids and ceremonial stairways.

\section{Huacas and ushnus}

Andean cosmology is also revealed by those unique Andean artifacts known as huacas, which possessed extraordinary powers and wisdom (D'Altroy 2000; Malville et al. 2008; Bray 2009) and ushnus, which are ceremonial platforms, sometimes with basins or wells, into which offerings were poured (Zuidema 1980; Staller 2008). Bray (2009) suggests a different, non-western ontology is needed to understand the meaning of huacas. Stone huacas and ushnus need to be interpreted with great care for they possess a deeper meaning than inert rocks or sighting devices for astronomical events. Recognition of the Chankillo towers as huacas in Inca times is suggested by an offering placed on the northern steps of tower \#1 (see Ghezzi \& Ruggles, this volume, p. 149).

\section{Stairways and processions}

The double stairways of each of the thirteen towers are clues for the ritual activities of Chankillo and suggest connections with Chavín de Huántar. Chavín was a place of important religious activity in its underground galleries connected by staircases and above ground plazas and mounds. Cornice fragments found in 1998 seem to depict a procession in which the lead figure is playing a Strombus trumpet and the second figure is carrying a Spondylus shell (Rick 2008). Both individuals have dorsal wings, perhaps feathers, suggesting shamanic flight as well as processional movement through its exterior and interior regions. Of special interest in our interpretation of Chankillo are the interior staircases of Chavín. Some stairways contain depressions suggesting that they were heavily used for processions (Rick 2008). Kembel (2008) notes the painting of interior plaster and suggests the three primary elevations were color coded, as if they corresponded to the three levels of the cosmos. Kembel documents 'hanging' stairways which can only be entered from above. They may have been used for ceremony and ritual for spectators below. Similarly incomplete or non-functioning staircases are well known in carved huacas in the Cusco valley, Chinchero, Ollantaytambo, and Machu Picchu (Fig. 1).

Rick (2008) suggests that the sunken plazas and mounds of Chavín cut off views of the outside world. They and the underground galleries created a world apart from normal experience, one in which only a limited number of priests and initiates could participate. The experiences in the underground galleries may have been attempts to demonstrate the access to great powers by the leaders of Chavin; in the galleries there were sounds generated by water and Strombus trumpets as well as manipulation of lighting on fierce images such as the Lanzón and the various tenon heads in the walls of the corridors. Kembel (2008) notes that after 750 BC changes in architecture produced an inward/outward, 
private/public duality consisting of private experiences in the underground galleries and public ceremonies in large external plazas (e.g. Plaza Mayor), terraces, and mounds.
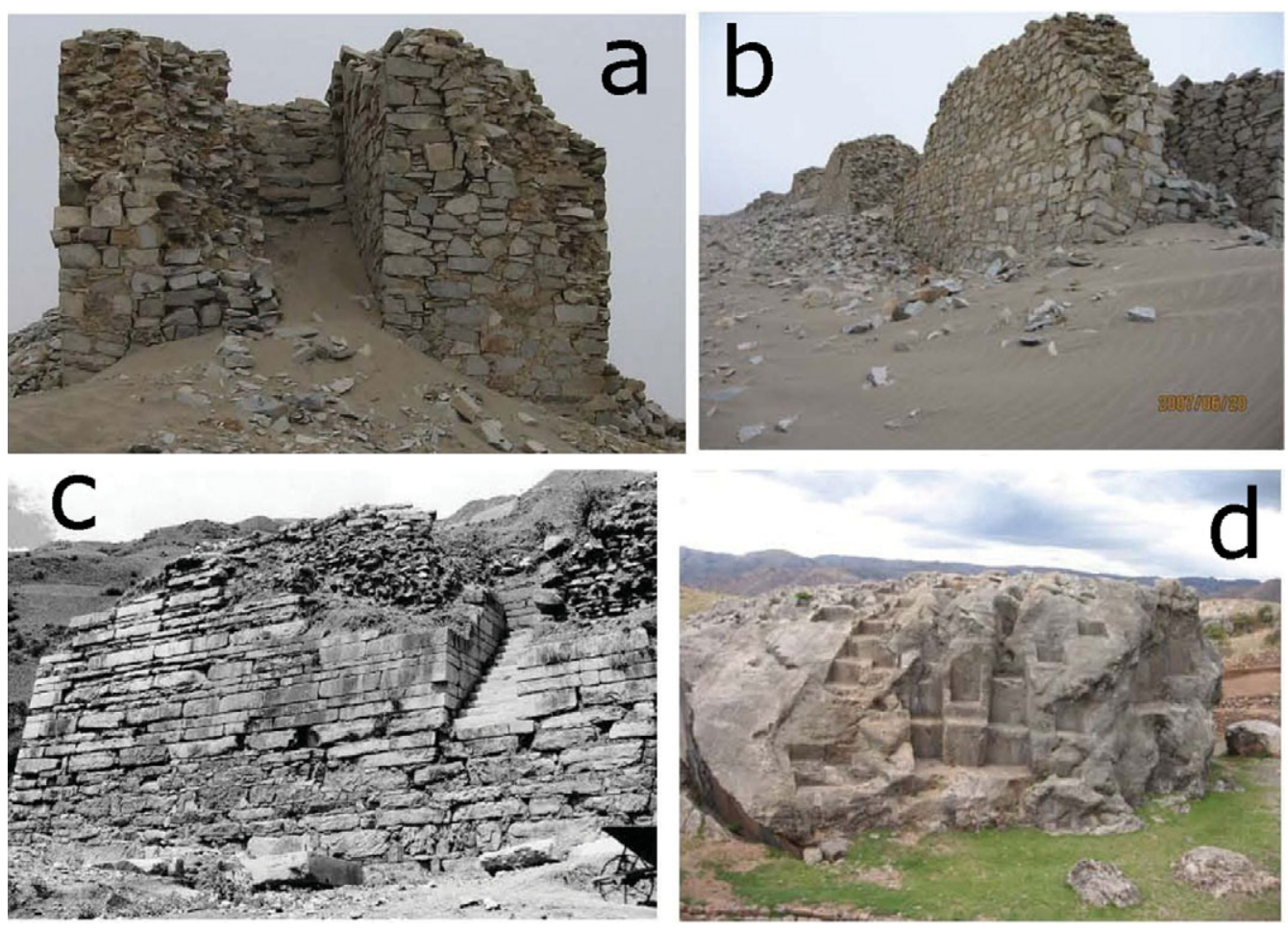

Figure 1. Andean Staircases: (a) Chankillo Tower \#1; (b) Sideview of Chankillo's lowest towers; (c) Chavín de Huántar, 'Hanging Staircase': East Face South Staircase; $(d)$ Cusco Huaca, Piedra Cansada ('the tired stone').

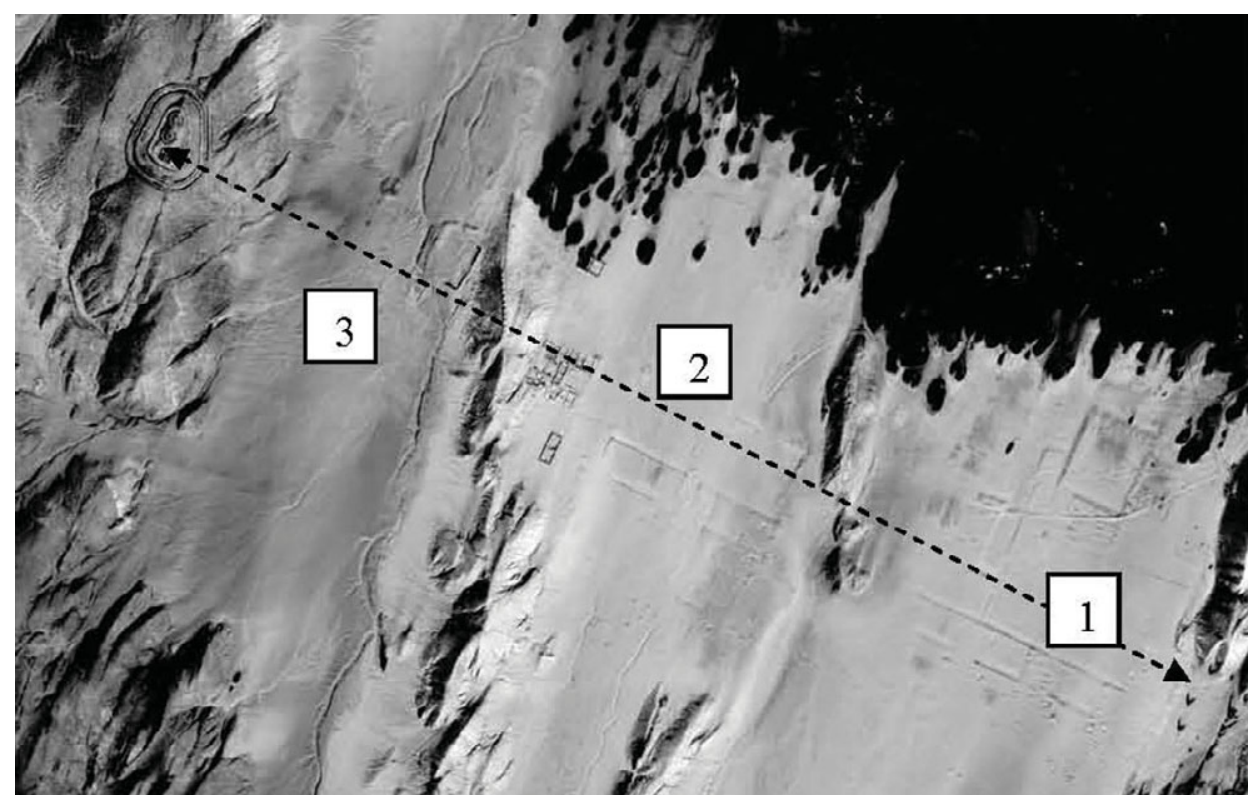

Figure 2. The Solar Axis of Chankillo. (IKONOS) 


\section{The solar axis and plazas of Chankillo}

The largest astronomical feature of Chankillo is the axis that extends some $3.1 \mathrm{~km}$ southeastward from the hilltop structure identified by Ghezzi (2006) as a fortified temple (Fig. 2). It aligns with December solstice sunrise and June solstice sunset. Similar solstitial axes are found at Caral (December solstice sunrise - Shady 2006), Sechín Bajo (earlier occupation December solstice sunrise with later orientation to June solstice sunrisePeter Fuchs \& Bernard Lorenz, priv. comm. 2010), Chavín (early U-shaped structure, December solstice sunrise - Rick 2008). In the case of Chankillo, with remarkably few exceptions, all walls, buildings, and plazas are parallel or perpendicular to this axis. The long sides of towers \#12 and \#13 are perpendicular to the axis. There are three sections with slightly different orientations (Table 1).

Table 1.

\begin{tabular}{cllll}
\hline Section & $\begin{array}{l}\text { Distance } \\
\text { from fortress } \\
(\mathrm{km})\end{array}$ & $\begin{array}{l}\text { Orientation } \\
\text { (degrees) }\end{array}$ & $\begin{array}{l}\text { Standard } \\
\text { deviation } \\
\text { (degrees) }\end{array}$ & $\begin{array}{l}\text { Number of } \\
\text { measured } \\
\text { walls }\end{array}$ \\
\hline 1 & $3.11-2.35$ & 114.29 & 0.8 & 8 \\
2 & $1.24-2.12$ & 115.58 & 0.66 & 13 \\
3 & $0.72-0.92$ & 121.25 & 0.68 & 8 \\
\hline
\end{tabular}

Sections 1 and 2 appear to be associated with either December solstice sunrise or June solstice sunset. June solstice sunset from the eastern plaza over tower \#13 may be the defining observation for section 2. Further to the south is another large plaza, from which the June solstice sun can be viewed setting over platform \#14 (175m due south of tower \#13, Malville et al. 2008). Section 3 contains the large plazas west of the towers and is oriented with the Temple of the Pillars. As seen from the center of that plaza the sun sets over the hill top structure at June solstice. The line from the Temple of the Pillars to the center of that plaza has an azimuth of $121.2^{\circ}$, corresponding to the orientation of section 3 .

\section{Stairways of Chankillo}

The sequence of double stairs on each of the thirteen towers suggests a dynamic rather than static function (Fig. 1). When approaching the first tower from below, the opening of the stairway is compelling and monumental. One does not know what lies on top or beyond. It seems an entry into another realm. Once one reaches the top of tower \#1, one discovers a second stairway leading down and then up to the top of the next tower. At each stage of the journey the surrounding vista opens up. Each of these platforms on the upward journey could have been an ushnu, a place for performing a ritual and/or making an offering.

Each successive tower carries one from the terrestrial to the solar realm. The entry into tower \#1 is from the north. There is a slow, almost imperceptible rotation of the stairways and platforms into parallelism with the solar axis (Fig. 3). On the highest tower a new vista appears. To the left, there are a series of walls, buildings, and enclosures that are in line with the rising sun at December solstice (Fig. 4 Top). If one has reached the top of the tower near sunset of June solstice, one's shadow stretches across the land in nearly perfect parallelism with the structures to the east. To the right, the northwest, lies the fortified temple. Looking down into the valley one can see the shadow of the temple crossing the center of one of the large enclosures (Fig. 4 Bottom). Celebrants who reached 


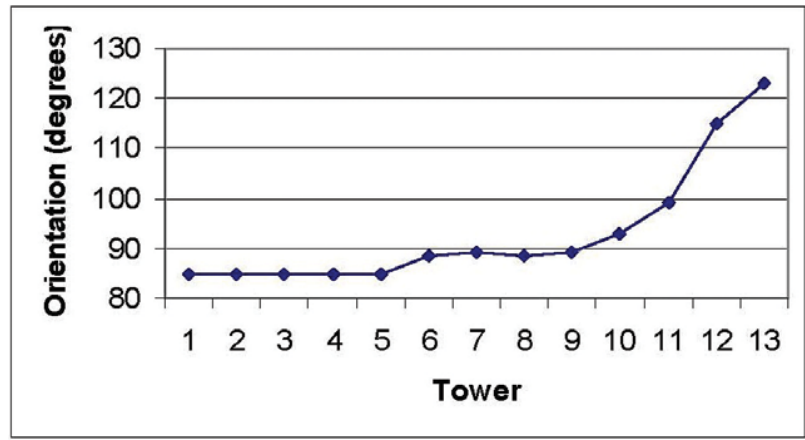

Figure 3. Orientations of the Chankillo towers: azimuths of perpendiculars to the long sides.

the highest tower on the evening of June solstice may have participated in a community ceremony taking place down in the valley. People may have gathered in the two plazas along the solar axis. To the east, people in the plaza of the large eastern building would see the sun setting approximately behind the thirteenth tower. The second ceremony occurring in the large enclosure to the west would witness the sun setting approximately over the Temple of the Pillars. The eastern wall of the fortress is low enough to allow a view from below of ceremonies performed in the temple. If this is the day of full moon close to June solstice, the full moon will be rising on the eastern horizon, approximately in line with one's shadow.

\section{Solar observatory}

A solar observatory is not an acknowledged element of Central Andean cosmology. If a horizon calendar had been developed using the profiles of the thirteen towers, it appears to have been an unintended consequence of the initial design of the towers. The monumental size of the towers is incommensurate with the small observing station proposed by Ghezzi \& Ruggles (2007). If the towers had been built for astronomical purposes, it seems likely a similarly monumental observation station would have been built. If the towers had been intended only for horizon markers, double staircases would not have been necessary. The presence of a scatter of pottery, shells, and lithics is essentially the only substantial evidence for an observatory (Ghezzi \& Ruggles 2007). The only calendrical event that is unambiguously marked by the towers from the western observing station is December solstice sunrise over the center of tower \#13. The June solstice sun misses tower \#1, rising $3.5^{\circ}$ to the north of its center (Ghezzi \& Ruggles 2007: supporting online material). This difference of 7 solar diameters should have been an unacceptable error if the tower had been built originally to mark June solstice. Another unsatisfactory feature would have been the equal spacing of the towers. If a meaningful calendar had been desired that marked divisions of the year perhaps based upon the moon, it would have involve variable spacing of the towers, with the largest spacing around equinox. The second observation station suggested by Ghezzi \& Ruggles was selected basically because it provided the desired view of the sunset over tower \#1. The site fails to provide a view of towers \#12 and \#13 or of December solstice sunset over a tower.

In fact, neither the western or eastern observing stations would have been selected $a$ priori as significant locations for public ceremony or astronomical ritual. Whether it is prior to Chankillo, at Chavín de Huántar at the Plaza Mayor (Kembel 2008) or later in the Inca Empire at the Plaza of Haucaypata, large public ceremonies were held in major plazas. There are two major plazas at Chankillo east of the towers and one west. All 
Figure 4. Top: June solstice sunset over the eastern plaza as viewed from tower \#13. Inset is view of sunset looking toward the tower from the plaza.

Bottom: June solstice sunset over plaza west of the towers (zone 3) viewed from the Temple of the Pillars in the Fortress. Dashed line passes through tower \#13 and the center of the plaza. Upper insert is the view of sunset (looking in the opposite direction) from the plaza. Lower insert shows the alignment of the stairway in the Temple with the plaza.
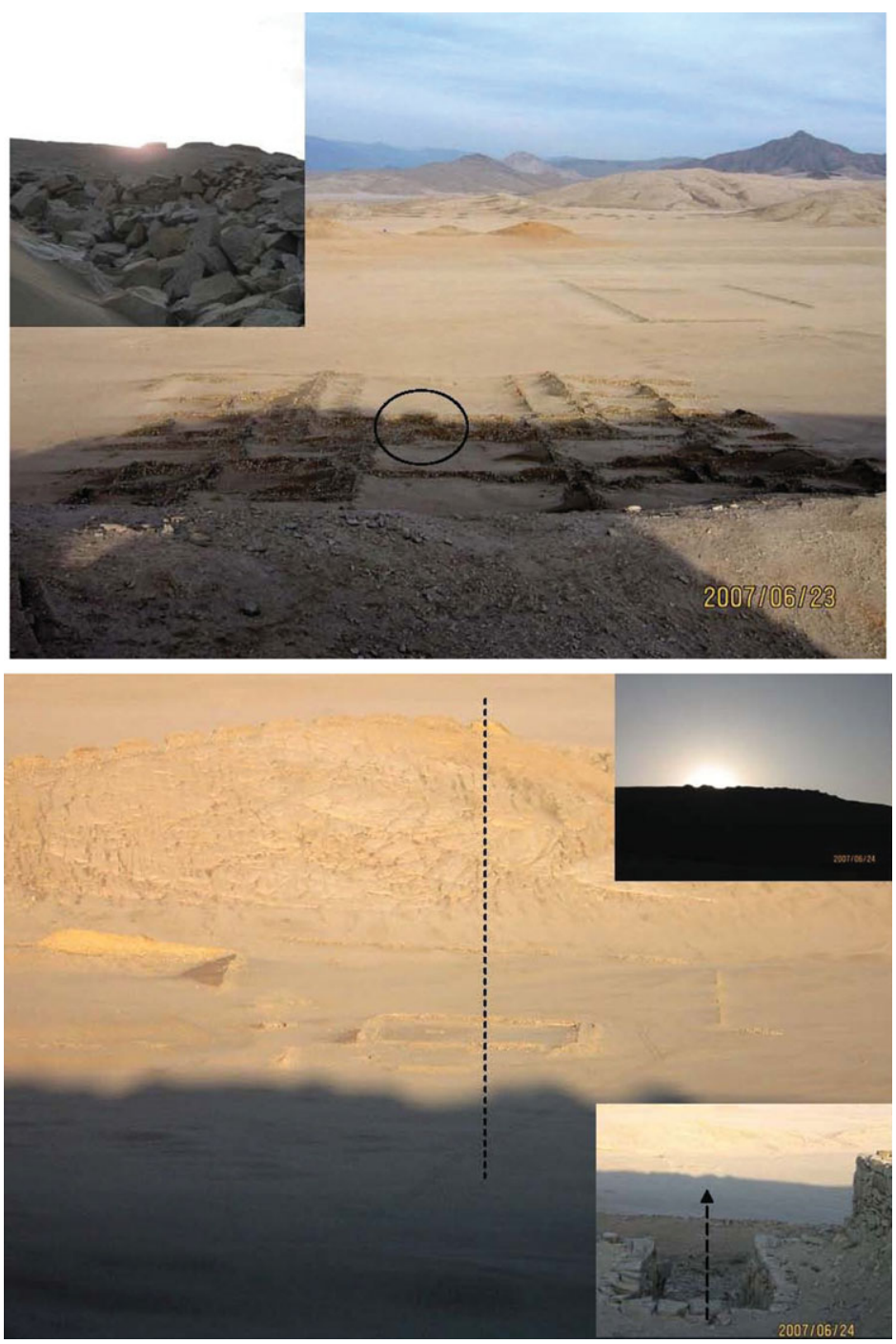

three appear to have been places for observing June solstice sunset, but none would have functioned as multiday calendrical stations.

\section{Concluding remarks}

There is no encouragement from the ethnography of the Central Andean cultural area for an exclusively astronomical interpretation of the thirteen towers. Solar markers in the Inca world, such as the pillars of Urubamba and Isla del Sol, do not have staircases and were elements of a ritual complex containing huacas and ushnus (Malville 2010). The putative western observing station may have served as a place for observing sunrise over one or more towers, but it is unlikely that calendrical observations were the primary reason for the construction of the towers.

A public/private duality, similar to that of Chavín de Huántar and elsewhere in the Andean culture area, may have been present at Chankillo. In the Inca world such a duality is found at pilgrimage centers such as Isla del Sol, Quespiwanka, Machu Picchu, and Tipon 
(Malville 2010; Zawaski \& Malville 2010). In Chankillo the major plazas and the towers may have been locations for public ceremonies and ritual processions, respectively. The fortified temple may have served as the private half of the ceremonial duality. Ghezzi (2006: 78) notes that room 3 of the Temple of the Pillars may have "served as a setting for the ritual activities of a more select audience". When viewed with this perspective, the great effort that went into construction of the massive walls, elaborate labyrinth-like gateways, and evident ceremonial function of the fortified temple are consistent with the monumental structures at Chavín and their restricted galleries. The low eastern wall of the hilltop structure allowed visual access from the plaza to the southeast, but the interior fortified temple had areas that allowed access to only a few celebrants. Ritual warfare noted by Ghezzi (2006) may have been one of the several ceremonies associated with the structure. Alternatively, the slingstones found below the structure may be markers of the final battle that resulted in the destruction of the temple.

\section{Acknowledgements}

I thank Carlos Aranibar, field assistant extraordinaire, for his thorough documentation of Chankillo during the solstice and major lunar standstill of June 2007.

\section{References}

Bennett, W. C. 1948, in W. C. Bennett (ed.), A Reappraisal of Peruvian Archaeology, Memoirs no. 4, Society for American Archaeology, Menasha WI, p. 1.

Bray, T. 2009, Cambridge Archaeological Journal 19, 357.

Cummins, T. 2008, in W. J. Conklin \& J. Quilter (eds), Chavin: Art, Architecture, and Culture, Cotsen Institute of Archaeology, Los Angeles, p. 279.

D'Altroy, T. 2000, The Incas, Blackwell, Oxford.

Dixon, E. J. 1999, Bones, Boats, and Bison: Archaeology and the First Colonization of Western North America, The University of New Mexico Press, Albuquerque.

Eliade, E. 1964, Shamanism, Pantheon Books, New York.

Ghezzi, I. 2006, in W. H. Isbell \& H. Silverman (eds), Andean Archaeology III: North and South, Springer, New York, p. 67.

Ghezzi, I. \& Ruggles, C. L. N. 2007, Science 315, 1239.

Gruhn, R. 2006, Mammoth Trumpet 21, 10.

Kembel, S. R. 2008, in W. J. Conklin \& J. Quilter (eds), Chavin: Art, Architecture, and Culture, Cotsen Institute of Archaeology, Los Angeles, p. 35.

Lynch, T. F. 1985, Guitarrero Cave, Academic Press, New York.

Malville, J. M. 2010, Journal of Cosmology 9, 3006.

Malville, J. M., Zawaski, M., \& Gullberg, S. 2008, in J. Vaiškūnas (ed.), Astronomy and Cosmology in Folk Traditions and Cultural Heritage, Archaeologia Baltica 10, Klaipèda University Institute of Baltic Sea Region History and Archaeology, Klaipėda, p. 175.

Moseley, M. 1975, The Maritime Foundations of Andean Civilization, Cummings, Menlo Park.

Rick, J. 2008, in W. J. Conklin \& J. Quilter (eds), Chavin: Art, Architecture, and Culture, Cotsen Institute of Archaeology, Los Angeles, p. 3.

Shady, R. 2006, in W. H. Isbell \& H. Silverman (eds), Andean Archaeology III: North and South, Springer, New York, p. 28.

Staller, J. E. 2008, in J. E. Staller (ed.), Pre-Columbian Landscapes of Creation and Origin, Springer, New York, p. 269.

Tello, J. 1923, Inca 1(1), 93-320.

Zawaski, M. J. \& Malville, J. M. 2010, Archaeoastronomy: The Journal of Astronomy in Culture $21,20$.

Zuidema, R. T. 1980, Revista de la Universidad Complutense 28, 317. 